\title{
Multidrug Resistance Protein 1
}

National Cancer Institute

\section{Source}

National Cancer Institute. Multidrug Resistance Protein 1. NCI Thesaurus. Code C17746.

Multidrug resistance protein $1(1280 \mathrm{aa}, \sim 141 \mathrm{kDa})$ is encoded by the human ABCB1 gene. This protein plays a role in both ATP-dependent transport of xenobiotics and resistance to chemotherapeutics. 